\title{
The Influence of Incentives and Motivation on Employee Performance of PT. Tozy Sentosa Surabaya
}

\author{
Nur Alifah Istiqomah* \& Elok Damayanti \\ Faculty of Economics and Business, Narotama University, Surabaya, Indonesia
}

\begin{abstract}
This study aims to determine the influence of incentives and motivation on the performance of employee of PT. Tozy Santosa Surabaya. This research is quantitative research. Population and sample based on questionnaire distribution to the employees of PT. Tozy Sentosa Surabaya was taken 63 respondents. Data collection techniques used interviews, observation and questionnaires. The data analysis used reliability test, validity test, classic assumption test and multiple linear analysis test. The results of the study, incentives and motivations simultaneously and partially significantly influence the employee performance of PT. Tozy Santosa Surabaya with significance value $<0.005$.
\end{abstract}

Keywords: Incentive; motivation; employee performance.

\section{Introduction}

High employee performance is expected by PT. Tozy Surabaya, the more employee who have high performance, the overall productivity will increase. So that activities within the organization will be able to survive in competition. The success of employee can be measured through the results they have done, the more effective and efficient a job is, the better the employee performance, it is one of the things that will be the subject of discussion. The role of the SPG in the company is very important, here an employee is also required to be able to sell products that are sold with maximum results in order to reach the target every month and get incentives according to their achievements. To get it all an employee must also have a high principle or motivation. Like how we can sell well and serve customers wholeheartedly without differentiating between other customers.

Based on the background of the research, the formulation of the problem in this study is a follows

1. Does the incentive have a partial influence on the performance of employee at PT.Tozy Sentosa Surabaya ?

2. Does motivation have a partial influence on the performance of employees at PT. Tozy Sentosa Surabaya ?

3. Does incentive and motivation have a simultaneous influence on the performance of employees at PT. Tozy Sentosa Surabaya?

\footnotetext{
* Corresponding author.

E-mail address: aliefa1994@gmail.com (Nur Alifah Istiqomah)
}

Quantitative Economics and Management Studies (QEMS) is licensed under an Attribution-NonCommercial-ShareAlike 4.0 International (CC BY-NC-SA 4.0) 


\section{Literature Review}

\subsection{Human Resource Management}

According to Bintoro and Daryanto (2017) human resource management is a science or method of how to regulate relationships and the role of resources (labor) owned by individuals efficiently and effectively and can be used optimally so that goals are met with the company, employee and the community becomes maximal ". In addition, according to Sutrisno (2016), argues that Human Resource Management (HRM) is: "Activities planning, procuring, developing, maintaining, and using HR to achieve goals both individually and organizationally."

\subsection{Incentive}

According to Hasibuan (2013) incentives are additional remuneration given to certain employees whose achievements are above standard achievement.

\subsection{Motivation}

Motivation is an encouragement to a series of processes of human behavior on achieving goals (Wibowo, 2007).

\subsection{Employee performance}

According to Robins (2006) in Bintoro and Daryanto (2017), performance is the amount of effort that individuals spend on their work.

\subsection{Previous Research}

Overall this study can be concluded that the independent variables have a significant influence on employee performance simultaneously and partially. From this it can be seen that among the two independent variables the most dominant influence on employee performance is Incentive because it has the highest $t$ value and beta coefficient (Anggriawan, Hamid, \& Mukzam, 2015). With the results of the analysis that has been carried out this research concludes that it is proven that there is a very strong and significant influence between the incentives on employee performance at PT. Suraco Jaya Abadi Motor Masamba Branch (Haedar, Ikbal, \& Gunair, 2016). Work environment, work discipline, motivation to work together and the impact simultaneously have a positive and significant effect on the performance of civil servants in the Madiun Regency DPRD. This is evident from the results of the SPSS calculation which is greater than $t$ table (Sidanti, 2015). The results of this study are formal education, work environment and work experience simultaneously have a significant effect on performance (Rasyid, Tobing, \& Syaharudin, 2016). Partially the formal education and work environment variables have no significant effect on performance. While the work experience variables partially have a significant effect on employee performance. The results of study Yuliana, Hasiholan, \& Gagah (2017) indicate that competence has a significant positive effect on employee performance. While work motivation is not significantly positive for employee performance. Chepkemoi (2018) show that incentives are very important in organizational performance. It is recommended that Kenya's forest services and other government institutions must embrace the process of reengineering in their operating systems to improve customer service, new teamwork and teamwork, reduce employee turnover which in turn results in improved organizational image. Deeb, Alananzeh, Tarhini, \& Masa'deh (2020) stated that incentives affect the performance of staff in the public sector in Jordan. And recommendations are made in order to focus on providing fair and adequate compensation when retired employees and salaries are in accordance with their salary level performance at work and interest in providing moral support and praise for staff to increase their level of performance. Gachengo \& Wekesa (2017) found that motivation had a statistically significant effect on employee performance at National Bank of Kenya. Shahzadi, et. al. (2014) indicate that there is a significant and positive relationship between employee motivation and employee performance. It was also concluded that intrinsic rewards have a significant positive relationship with employee performance and employee motivation. 


\section{Methods}

\subsection{Type of Research}

This type of research is causal research (looking for a cause and effect by using a hypothesis), where the object of this study is a case study conducted on employees of PT. Tozy Sentosa Surabaya. This study will use a quantitative approach, according to Sugiyono (2016) quantitative method is a scientific approach that views a reality that can be classified, concrete, observable, and measurable, the relationship of variables is causal where the research data is in the form of numbers and the analysis uses statistics. The independent variables in this study are incentives, motivation and dependent variables of employee performance. The purpose of this study is more towards the results of generalizations, explaining phenomena in a more measurable manner and various evidences to be found. Data collection to obtain results of discussion, analysis and conclusions that can be justified.

\subsection{Population and Sample}

The population in this study were employees of PT. Tozy Sentosa Surabaya, amounting to 63 employee. Samples are part of the number and characteristics possessed by the population (Sugiyono, 2016). In this study the sampling technique used is saturated sampling, saturation is a sampling technique if all members of the population are used as samples or studies that want to make generalizations with a very small error. Another term saturated sample is a census, where members of the population are sampled (Sugiyono, 2016). Based on these opinions, the research sample is the employees of PT. Tozy Sentosa Surabaya, amounting to 63 employee

\subsection{Data Collection Method}

The data sources used in this study use primary data and secondary data. Primary data are data obtained directly from the object of research, namely employees of PT. Tozy Sentosa Surabaya. And secondary data, researchers get from data that has been processed by third parties, through books, libraries, libraries, and sources from the internet.

\subsection{Operational Definition of Research Variable}

$\mathrm{X} 1$ : Incentives

Incentives are remuneration paid to certain workers whose achievements are above standard prestige.

X2: Motivation

Motivation is an encouragement to a series of processes of human behavior on achieving goals.

Y: Employee Performance

Employee Performance is the amount of effort that individuals spend on their work.

\subsection{Data Analysis Method}

\subsubsection{Reliability and Validity Test}

Reliability Test is actually a tool to measure a questionnaire which is an indicator of a variable or construct. A questionnaire is said to be reliable or handle if a person's answer to a question is consistent or stable from time. Questionnaire items are said to be reliable if cronbach's alpha> 0.06 and it is said to be unreliable if cronbach's alpha $<0.06$ (Ghozali, 2012). Test validity is used to measure the validity of a questionnaire. What will be measured by the questionnaire. These validity testers use Pearson Correlaation by calculating the correlation between the values obtained from the questions. A question is said to be valid if the level of significance is below 0.5 (Ghozali, 2012).

\subsubsection{Multiple Regression Analysis Model}

The data analysis technique used in this study is multiple regression analysis techniques. This analysis is intended to 
determine the effect of Incentives (X1) and Motivation (X2) on employee performance (Y):

$$
\mathrm{Y}=a+\mathrm{b}_{1} \mathrm{X}_{1}+\mathrm{b}_{2} \mathrm{X}_{2}+e
$$

Description:

$$
\begin{array}{ll}
\mathrm{Y} & =\text { Employee Performance } \\
a & =\text { Constant Value } \\
\mathrm{b}_{1}, \mathrm{~b}_{2} & =\text { regression coefficient } \\
\mathrm{X}_{1} & =\text { Incentives } \\
\mathrm{X}_{2} & =\text { Motivation } \\
e & =\text { Error }
\end{array}
$$
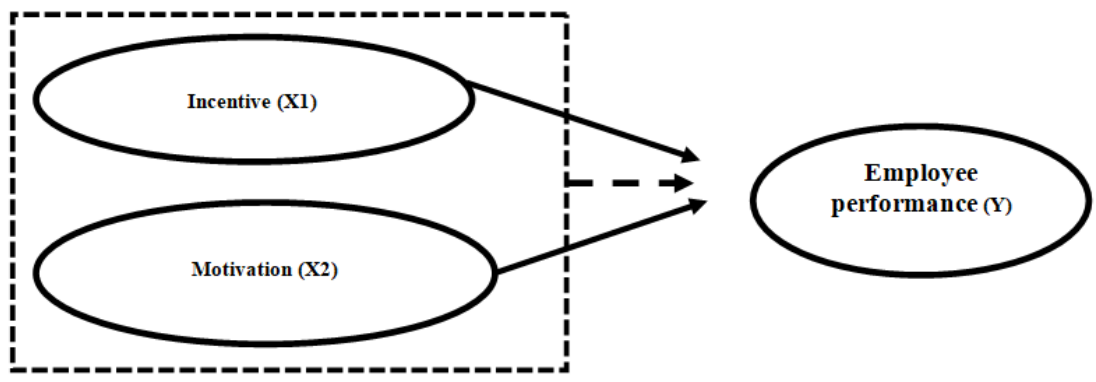

Fig. 1 Conceptual framework

\section{Result and Discussions}

\subsection{Reliability and Validity}

Based on the research, the alpha cronbanch value is 836 , which means that it is above the acceptance limit of 0.6 , therefore, the research instrument for the relationship between variables shows good consistency and acceptable data.

\begin{tabular}{|c|c|c|c|c|c|c|}
\hline \multirow{2}{*}{\multicolumn{2}{|c|}{ Model }} & \multicolumn{2}{|c|}{ Unstandardized Coefficients } & \multirow{2}{*}{\begin{tabular}{c|}
$\begin{array}{c}\text { Standardized } \\
\text { Coefficients }\end{array}$ \\
Beta
\end{tabular}} & \multirow[b]{2}{*}{$\mathrm{t}$} & \multirow[b]{2}{*}{ Sig. } \\
\hline & & B & Std. Error & & & \\
\hline 1 & (Constant) & 4.691 & 2.270 & & 2.066 & .043 \\
\hline & TOTAL_I & .685 & .115 & .587 & 5.955 & .000 \\
\hline & TOTAL_M & 229 & .102 & .221 & 2.244 & .029 \\
\hline
\end{tabular}
Based on the research value of the correlation index for the relationship between the independent variables (Incentives and Motivation) and the dependent variable (Employee Performance) greater than 0.3 and below the significant level of $5 \%(0.05)$. Therefore, the data is considered valid.

\subsection{Multiple Linear Regression Result}

Table 1. Multiple Linear Regression Result

Coefficients $^{\mathrm{a}}$

a. Dependent Variable: TOTAL_K

Regression equation models that can be written from these results in the form of standard form regression equations are as follows: 
$\mathrm{Y}=4,691+0,685 \mathrm{X} 1+0,229 \mathrm{X} 2+\mathrm{e}$

1. Constant value of 4.691 this shows that if incentives (X1) and motivation (X2) equal zero, then the employee's performance is 4,691

2. Incentive value (X1) 0.685. This shows if the incentive (X1) increases by one unit, it will improve employee performance $(\mathrm{Y})$ by 0.685 assuming the magnitude of the motivation variable (X2) is constant.

3. Motivational coefficient of efficiency (X2) 0.229. This shows that if motivation (X2) increases by one unit, it will improve employee performance (Y) by 0.229 units assuming the magnitude of the incentive variable (X1) is constant

\subsection{Result of $R$ Square}

Table 2. Result of R Square

\begin{tabular}{|l|r|r|r|c|}
\hline Model & R & R Square & Adjusted R Square & $\begin{array}{c}\text { Std. Error of the } \\
\text { Estimate }\end{array}$ \\
\hline 1 & $0.687^{\mathrm{a}}$ & 0.472 & 0.455 & 1.54245 \\
\hline
\end{tabular}

a. Predictors: (Constant), TOTAL_M, TOTAL_I

b. Dependent Variable: TOTAL_K

The value of $\mathrm{R}$ Square is 472 , which means that all independent variables: Incentives and Motivations have a positive relationship with Employee Performance

\subsection{Test of Classical Assumption}

\subsubsection{Multicollinearity Result}

Based on the fig. 2, data that spreads near the diagonal line and follows the direction of the diagonal line. This proves that the model has passed the normality test.

\section{Normal P-P Plot of Regression Standardized Residual}

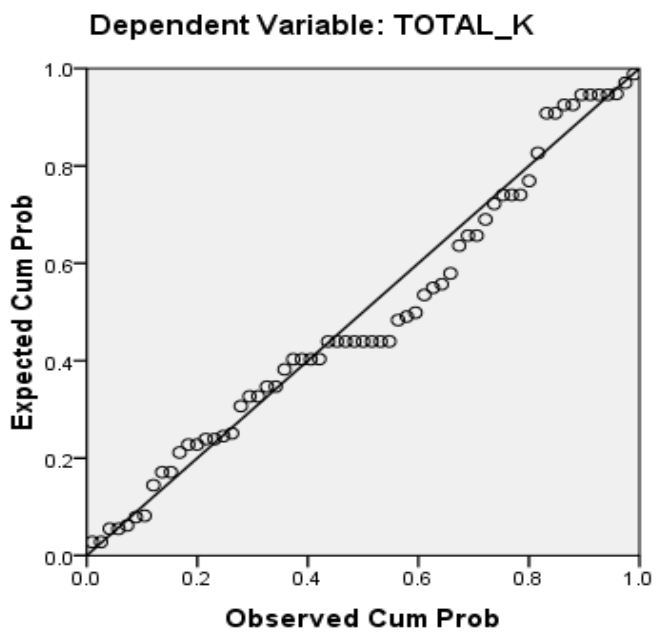

Fig. 2. Normality Test Result 
Tabel 3. Multicollinearity Result

\begin{tabular}{|l|l|l|l|}
\hline \multirow{2}{*}{ Variable } & \multicolumn{2}{|c|}{ Collinearity Statistics } & \multirow{2}{*}{ Status } \\
\cline { 2 - 3 } & Tolerance & VIF & \\
\hline X1 & 0,755 & 1,324 & free multicollinearity \\
\hline X2 & 0,755 & 1,324 & free multicollinearity \\
\hline
\end{tabular}

Source: SPSS Output, 2019

Incentive tolerance is 0.755 , and motivation is 0.755 which means that the tolerance value of each variable is more than 0.1. The VIF value of the Incentive is 1.324 and Motivation is 1.324 which means that the value of the two variables is less than 10. Because the tolerance value is more than 0.1 and the VIF value is less than 10 studies are free from multicollinearity.

\subsubsection{Heteroscedasticity Result}

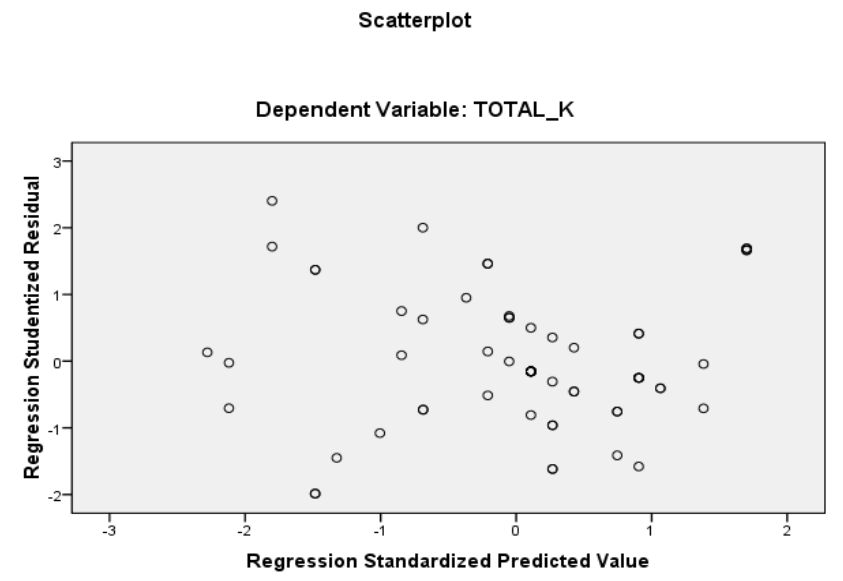

Fig. 3. Heteroscedasticity Result

The pattern of dots spreads and does not make a clear pattern. The points spread above and below 0 (zero) at Y and that proves that the model is free from heteroscedasticity.

\subsubsection{Hypothesis Testing}

a) F-Test

The F-test is used to determine all effects of all independent variables on the dependent variable. This test is done by comparing the $\mathrm{F}_{\text {count }}$ value with $\mathrm{F}_{\text {table }}$ value at $\alpha=0.05$.

Table 4. Result of F Test

ANOVA $^{b}$

\begin{tabular}{|ll|r|r|r|r|r|}
\hline Model & & Sum of Squares & df & Mean Square & F & Sig. \\
\hline 1 & Regression & 127.854 & 2 & 63.927 & 26.870 & $0.000^{\mathrm{a}}$ \\
& Residual & 142.749 & 60 & 2.379 & & \\
& Total & 270.603 & 62 & & & \\
\hline
\end{tabular}




\begin{tabular}{|c|c|c|c|c|c|c|}
\hline \multicolumn{7}{|c|}{ ANOVA $^{\mathbf{b}}$} \\
\hline & & Sum of Squares & $\mathrm{df}$ & Mean Square & $\mathrm{F}$ & Sig. \\
\hline \multirow[t]{3}{*}{1} & Regression & 127.854 & 2 & 63.927 & 26.870 & $0.000^{\mathrm{a}}$ \\
\hline & Residual & 142.749 & 60 & 2.379 & & \\
\hline & Total & 270.603 & 62 & & & \\
\hline
\end{tabular}

The F-test is used to determine all effects of all independent variables on the dependent variable. This test is done by comparing the $F_{\text {count }}$ value with $F_{\text {table }}$ value at $\alpha=0.05$. The overall effect of Incentives (X1) and Motivation (X2) on employee performance $(\mathrm{Y})$ is very significant.

b) T-Test

Table 5. Result of T-Test

Coefficients $^{\mathrm{a}}$

\begin{tabular}{|c|c|c|c|c|c|c|}
\hline \multirow{2}{*}{\multicolumn{2}{|c|}{ Model }} & \multicolumn{2}{|c|}{ Unstandardized Coefficients } & \multirow{2}{*}{$\begin{array}{c}\begin{array}{c}\text { Standardized } \\
\text { Coefficients }\end{array} \\
\text { Beta }\end{array}$} & \multirow[b]{2}{*}{$\mathrm{T}$} & \multirow[b]{2}{*}{ Sig. } \\
\hline & & $\mathrm{B}$ & Std. Error & & & \\
\hline \multirow[t]{3}{*}{1} & (Constant) & 4.691 & 2.270 & & 2.066 & .043 \\
\hline & TOTAL_I & .685 & .115 & .587 & 5.955 & .000 \\
\hline & TOTAL_M & .229 & .102 & .221 & 2.244 & .029 \\
\hline
\end{tabular}

a. Dependent Variable: TOTAL_K

Table 5 shows that the incentive titung (X1) is 5.955 with sig 0,000 smaller than 0.05 , H0 is rejected and Ha is accepted. Therefore incentives have a significant influence on Employee Performance. Table 5 shows that thitung Motivation (X2) is 2,244 with sig 0.029 smaller than 0.05 , H0 is rejected and Ha is accepted. Therefore Motivation has a significant influence on Employee Performance

\section{H1: The Influence of Incentives and Motivation on Employee Performance}

The first hypothesis proposed states that Incentives and Motivation simultaneously on the performance of PT. Tozy Sentosa Surabaya employees have been proven by the results of the F test value of 26,870.

\section{H2: Incentives for Employee Performance}

The second hypothesis proposed states that incentives are partial to the performance of employees of PT. Tozy Sentosa Surabaya this has been proven by the value of the t test results 2.066 .

\section{H3: Motivation on Employee Performance}

Employees of PT. Tozy Sentosa Surabaya, this has been proven by the results of the t test value of 2.066.

\section{Conclusions}

\subsection{Conclusion}

Based on the results of the research and analysis that has been done can be stated several things which are the conclusions of this study, namely: 
1. Simultaneously both independent variables of incentives and motivation have a positive effect on the performance of employees of PT. Tozy Sentosa Surabaya.

2. Partially the independent variable of incentives has a positive influence on the performance of employees of PT. Tozy Sentosa Surabaya.

3. Partially the independent variables of motivation have a positive influence on the performance of employees of PT. Tozy Sentosa Surabaya.

4. From the results of the determination test obtained the adjusted $\mathrm{R}$ square value of 0.455 which means that $45.5 \%$ of the variation in the variable incentives and motivation influence the performance of employees of PT. Tozy Sentosa Surabaya $(\mathrm{Y})$ is 0.455 which means that the remaining $45.5 \%$ is 0.545 which means that $54.5 \%$ is influenced by other variables not discussed in this study.

\subsection{Recommendation}

Based on the results of the research and conclusions above, the researcher needs to provide suggestions as follows:

1. Only when showing the incentives and motivation that it has a personal impact and also simulates the performance of employees of PT. Tozy Sentosa Surabaya. However, in the future, PT. Tozy Sentosa Surabaya must have been an indicator - an incentive and motivation indicator to the karyawār. So, this means that to get a better performance and to make it possible for me to be on the way to being hungry in the past until the end of my life.

2. It is recommended that PT. Tozy Sentosa Surabaya pay attention to the opinions of its subordinates, so that subordinates feel more valued by the leadership, besides that the leadership should be willing to listen to the problems faced by employees. Therefore it can be done well by the company, so that it can be a motivation for employees to improve their performance.

3. For further researchers it is expected to develop this research with variables that have not been studied in this study such as compensation and training.

\section{References}

Anggriawan, K. H., Hamid, D., \& Mukzam, M. D. (2015). Pengaruh insentif dan motivasi terhadap kinerja karyawan (studi pada karyawan CV Suka Alam (Kaliwatu Rafting) Kota Batu, Jawa Timur). Jurnal Administrasi Bisnis, 28(1), 50-55.

Bintoro \& Daryanto. (2017). Manajemen Penilaian Kinerja Karyawan, Yogyakarta: Penerbit Gaya Media.

Chepkemoi, J. (2018). Effect of Incentives on Employee Performance At Kenya Forest Service Uasin Gishu County. IOSR Journal of Business and Management (IOSR-JBM), 20(3), 26-32.

Deeb, A., Alananzeh, O. A., Tarhini, A., \& Masa'deh, R. E. (2020). Factors affecting job performance: the case of Jordanian hotels' kitchen staff. International Journal of Public Sector Performance Management, 6(3), 340360.

Gachengo, V., \& Wekesa, S. (2017). Influence of motivation on employee performance: a case of national bank of Kenya. Int. J. Bus. Manag. Soc. Res, 3(02), 179-185.

Ghozali, I. (2012). Aplikasi Analisis Multivariate Dengan Program IBM SPSS 20, Edisi Keenam. Semarang: Universitas Diponegoro.

Haedar, H., Ikbal, M., \& Gunair, G. (2016). Pengaruh pemberian insentif terhadap kinerja karyawan pt. suraco jaya abadi motor di masamba kabupaten luwu utara. Equilibrium: Jurnal Ilmiah Ekonomi, Manajemen dan Akuntansi, 5(1).

Hasibuan, M. S. (2013). Manajemen sumber daya manusia. Jakarta: Bumi Aksara. 
Rasyid, M. N., Tobing, D. S., \& Syaharudin, M. (2016). Pengaruh Motivasi dan Insentif terhadap Kinerja Karyawan Melalui Komitmen Organisasi Pada Senyum Media Stationary Jember. BISMA: Jurnal Bisnis dan Manajemen, $10(3), 343-354$.

Shahzadi, I., Javed, A., Pirzada, S. S., Nasreen, S., \& Khanam, F. (2014). Impact of employee motivation on employee performance. European Journal of Business and Management, 6(23), 159-166.

Sidanti, H. (2015). Pengaruh lingkungan kerja, disiplin kerja dan motivasi kerja terhadap kinerja pegawai negeri sipil di sekretariat dprd kabupaten madiun. Jurnal Jibeka, 9(1), 44-53.

Sugiyono. (2016). Metode Penelitian Kuantitatif, Kualitatif dan R\&D. Bandung: PT Alfabet.

Sutrisno, E. (2016). Manajemen Sumber Daya Manusia, cetakan kedelapan. Penerbit: Kencana Prenada Media Group, Jakarta.

Wibowo. (2007). Manajemen kinerja. Jakarta: PT Rajagrafindo Persada.

Yuliana, M., Hasiholan, L. B., \& Gagah, E. (2017). Pengaruh Lingkungan Kerja, Disiplin Kerja, dan Kepuasan Kerja Terhadap Kinerja Karyawan BMT Taruna Sejahtera Ungaran. Journal of Management, 3(3). 